\title{
GRØNNERE TEKSTILER PÅ SYKEHUS
}

Veiledning til grønne innkjøp i helsevesenet

(11) Nordisk ministerråd 


\section{Grønnere tekstiler på sykehus}

Veiledning til grønne innkjøp i helsevesenet

David Watson, PlanMiljø

Rikke Fisher-Bogason; PlanMiljø

ISBN 978-92-893-5064-8 (PRINT)

ISBN 978-92-893-5065-5 (PDF)

ISBN 978-92-893-5066-2 (EPUB)

http://dx.doi.org/10.6027/ANP2017-742

ANP 2017:742

๔ Nordisk ministerråd 2017

Layout: Gitte Wejnold

Omslagsfoto: Pexels.com

Foto: Scanpix.dk

www.norden.org/nordpub

Download nordiske publikationer: www.norden.org/nordpub

\section{Det nordiske samarbeidet}

Det nordiske samarbeidet er en av verdens mest omfattende regionale samarbeidsformer. Samarbeidet omfatter Danmark, Finland, Island, Norge og Sverige samt Færøyene, Grønland og Åland.

Det nordiske samarbeidet er både politisk, økonomisk og kulturelt forankret, og er en viktig medspiller i det europeiske og internasjonale samarbeid. Det nordiske fellesskapet arbeider for et sterkt Norden i et sterkt Europa.

Det nordiske samarbeidet ønsker å styrke nordiske og regionale interesser og verdier i en global omverden. Felles verdier landene imellom bidrar til å styrke Nordens posisjon som en av verdens mest innovative og konkurransekraftige regioner.

Nordisk ministerråd

Ved Stranden 18

1061 København K

www.norden.org 


\section{GRØNNERE TEKSTILER PÅ SYKEHUS}

Veiledning til grønne innkjøp i helsevesenet 


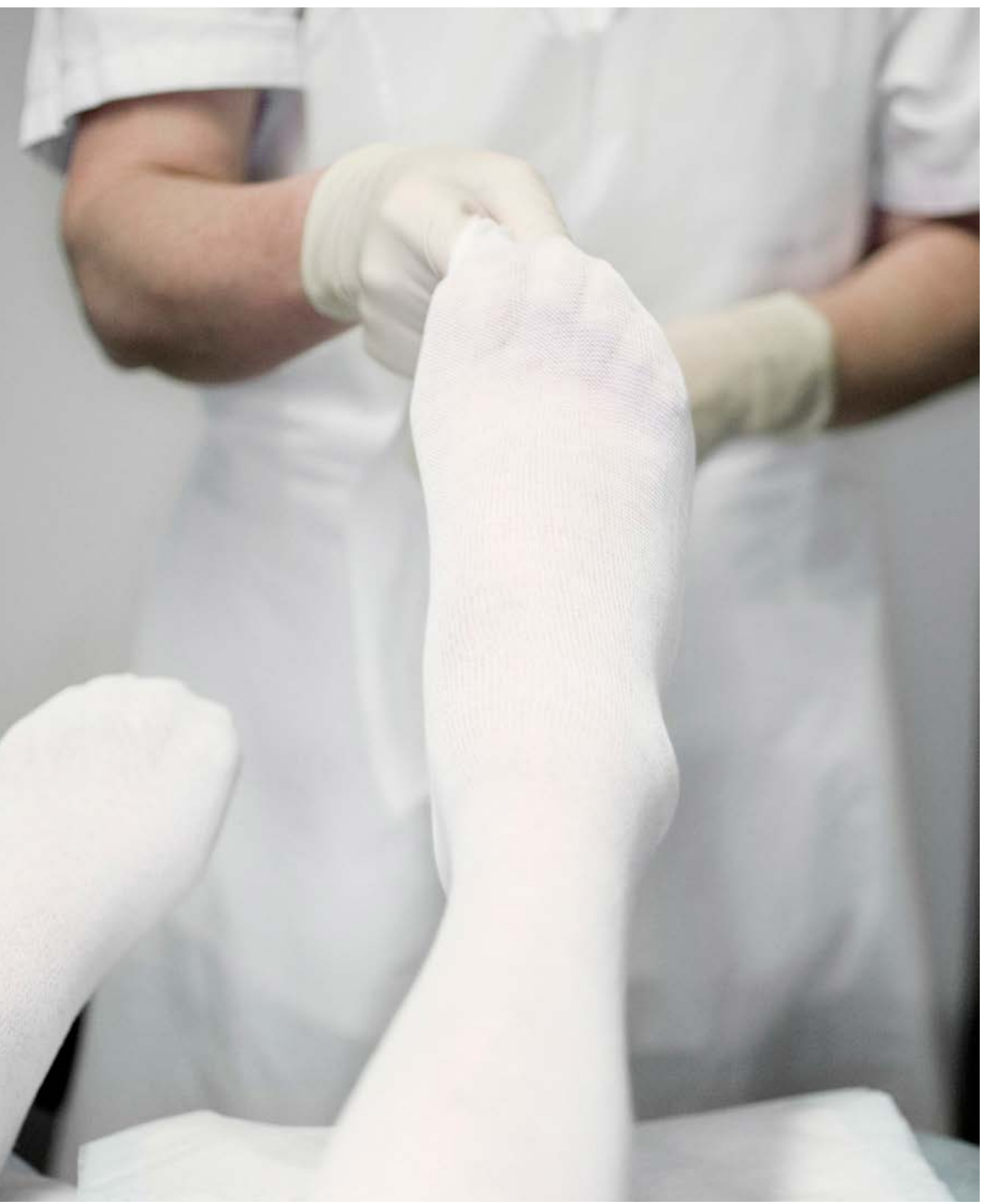




\section{INNHOLD}

6 Slik brukes denne veiledningen

8 Del 1

De viktigste aspektene

10 Del 2

Innkjøpsprosessen, markedsdialog og innovasjon

15 Del 3

Lenker til nyttige dokumenter og ressurser

22 Del 4

Kort oversikt over miljømerker

24 Del 5

Valg av fiber

28 Del 6

Tekstiler til engangsbruk kontra tekstiler til flergangsbruk

30 Del 7

Bruke livsløpskostnader

33 Del 8

Om veiledningen og nettverket bak 


\section{Slik brukes denne veiledningen}

Denne veiledningen er utviklet for innkjøpere i sykehussektoren som planlegger å innhente anbud på tekstilprodukter og/eller tekstiltjenester. Veiledningen vil være til hjelp $i$ å definere rimelige og gjennomførbare miljøkriterier og vil gi bakgrunnsinformasjon for de viktigste aspektene å vurdere når du har som mål å redusere miljøpåvirkningen ved bruk av tekstiler.

Veiledningsdokumenter kan være til stor hjelp gjennom å bistå innkjøpere og inspirere dem til å realisere potensialet for miljø- og samfunnsmessige forbedringer via offentlige innkjøp. I denne veiledningen får du informasjon om de miljømessige konsekvensene av tekstilinnkjøp og om tilgjengelige miljømerker, og du finner bruksklare kriterier og får vite hvilke aspekter av tekstilers livssyklus som det er viktig å ta tak i. Det er imidlertid viktig at enhver anbudsprosess settes i den riktige organisasjons- og produktspesifikke sammenhengen, og at innkjøperen vurderer alle virkningene på organisasjonen og brukerne av valgene som gjøres når kriteriene defineres.

Hygienehensyn vil alltid ha høyest prioritet i beslutninger relatert til tekstiler $\mathrm{i}$ helsesektoren. Man skal heller ikke gå på akkord med brukerkomfort. Det er mulig å ta hensyn til disse to aspektene samtidig som man reduserer miljøpåvirkningen. 


\section{ET KOMPLEKST INNKJØPSLANDSKAP}

Det finnes mange ulike modeller for innkjøp av tekstiler til helsesektoren i de nordiske landene. Forskjellene kan blant annet ligge i hvordan innkjøp organiseres, og hva som kjøpes inn.

\section{- Hvordan organiseres innkjøp?}

Dette er en sammensatt problemstilling som varierer fra land til land, og i noen tilfeller fra region til region. I Danmark har regionene definert et rammeverk for innkjøp som de enkelte sykehusene bruker for de daglige bestillingene. I Norge har Sykehusinnkjøp, en sentral innkjøpsorganisasjon inngått rammeavtale for alle helseforetakene som kjøper sine helsetekstiler og helseforetakene må kjøpe sine tekstiler hos valgt leverandør. I Sverige har man en ad hoc-struktur. Regioner/landsting samarbeider innimellom om rammeverk for innkjøpsavtaler, men de enkelte sykehusene håndterer mindre innkjøp på egenhånd. Generelt vil rammeverkavtaler redusere byråkrati og ressursbehov ved utarbeidelse av anbudsinnbydelser, og de kan bidra til å senke prisene på grunn av volum.

\section{- Hva er det som kjøpes inn?}

Et typisk rammeverk vil omfatte mange titalls, om ikke hundretalls, tekstilprodukter, som sengetøy, pasientbekledning, arbeidstøy til personale og tekstiler til operasjonsstuer. Sykehusforetak kan eventuelt, eller i tillegg, kjøpe inn vaskeritjenester. Spesielt vaskeritjenester kjøpes ofte inn av individuelle sykehus eller grupper av sykehus som har tilknytning til et vaskeri, ikke på regionalt eller nasjonalt nivå. Vaskerier kan være privateide, de kan være eid av sykehusforetaket, men drives med et uavhengig budsjett, eller de kan være offentlig eid av et partnerskap av sykehus og lokale myndigheter. 
Del 1

\section{De viktigste aspektene}

Forbruket av tekstiler står for 4-6 \% av de totale miljøpåvirkningene forårsaket av europeisk forbruk'. Disse påvirkningene skjer både under produksjonen av tekstilene og vedlikeholdet av dem under bruk. For tekstiler til flergangsbruk dominerer bruksfasen, mens produksjonsfasen står for de største miljøpåvirkningene knyttet til tekstiler til engangsbruk.

Denne veiledningen fokuserer på innkjøp, dvs. hvordan innkjøpere i helseforetak kan redusere miljøpåvirkningene fra innkjøpene sine. Innkjøpere er imidlertid kanskje også interessert i å oppnå bærekraftige innkjøp, som også omfatter etiske sider ved produktleveranser. I boksen på side 18 er det oppført noen ressurser som hjelp til utvikling av etiske kriterier.

For å redusere miljøpåvirkninger er det en god idé å fokusere på to områder: valget av tekstiler du kjøper inn / leier, og hvordan de vaskes (selv om du kanskje ikke har innflytelse over sistnevnte). Det er også viktig å være klar over forbindelsen mellom disse spørsmålene. Ulike fibertyper kan kreve ulike behandlingsmetoder.

Du kan vurdere begge disse spørsmålene vavhengig av om du kjøper inn og eier tekstilene og kjøper vaskeritjenester, eller kjøper komplette tekstiltjenester, inkludert en leiemodell.

Produksjonsbaserte påvirkninger: Mange produksjonspåvirkninger skyldes bruk av kjemikalier og energi i produksjonen. I tillegg kan tekstilprodukter inneholde rester av noen av de mange farlige kjemikaliene som brukes i produksjonen, og disse kan utgjøre en helsefare for sensitive brukere.

Disse problemstillingene håndteres godt av de ulike miljømerkene, spesielt det nordiske svanemerket og
EUs miljømerke EU Ecolabel (også kalt EU-blomsten) (se del 4, side 22), og av tekstilkriteriene definert av EUs GPP (Green Public Procurement - grønne offentlige anskaffelser). De dekkes også av ulike nasjonale retningslinjer for grønne offentlige anskaffelser (se del 3, side 19).

Valget av fibertype er også viktig. Bomullsproduksjon gir betydelige påvirkninger, spesielt på grunn av det høye forbruket av plantevernmidler, jordbruksland og vann. Å velge økologisk reduserer noen av disse påvirkningene, men man kan også redusere miljøpåvirkningene ved å bytte til andre fibre, for eksempel polyester. Du finner mer om dette i del 5, side 24-25.

En svært viktig, men ofte oversett måte å redusere alle produksjonspåvirkninger på er å forlenge brukstiden til produktene så mye som mulig. Det vil også spare penger (se del 7, side 30-31). Som innkjøper kan du bidra ved å 1) velge en holdbar fiber (se del 5 , side 24-25), 2) velge fargene som er mest motstandsdyktige mot bruk av pasienter og personale og mot vask, og 3) definere kriterier for vaskeritjenester som reduserer slitasjen på tekstilene. Noen miljømerker (se del 4) omfatter holdbarhetskriterier, for eksempel europeiske EN-standarder og nasjonale standarder for tekstiler ${ }^{2}$, men disse er svært enkle/grunnleggende. Det beste er å få dokumentasjon fra leverandører på hvor mange bruks-/vaskesykluser tekstilene skal tåle.

\footnotetext{
${ }^{1}$ EEA (2014) Environmental Indicator Report 2014 http://www.eea.europa.eu/publications/environmental-indicator-report-2014

${ }^{2}$ Se for eksempel internationale og norske standarder udgivet af Norsk Standard https://www.standard.no/no/Nettbutikk/ produktkatalogen/?ProdCat $=11360430$
} 


\section{SYKEHUSLOGOER OG UNNGÅELSE AV SLøSING}

Det finnes to situasjoner som kan føre til kassering av store mengder ellers velfungerende tekstiler i helsevesenet: 1) en endring hos tjenesteleverandøren som du leier tekstiler fra, og 2) en merkevareendring / endring av logoen til sykehuset, distriktet eller regionen.

Det finnes flere metoder for å unngå denne betydelige sløsingen med ressurser:

1. Før inn i kontrakten med leverandøren av tekstiltjenester at tekstilene skal kunne kjøpes av sykehuset på slutten av kontraktsperioden.

2. Velg nøytral merking av tekstilene, slik at de kan brukes av flere helsedistrikter, sykehus osv.

3. Spør leverandøren om tekstilene kan merkes med avtakbare logoer.

Påvirkninger i bruksfasen: Hygiene har naturligvis høyest prioritet ved vasking av tekstiler. Det finnes imidlertid måter å redusere påvirkningene fra vask på uten at det går på bekostning av hygiene. De omfatter høyere vann- og energieffektivitet, bruk av grønnere vaskemidler og miljøeffektiv logistikk. I enkelt land (f.eks. Norge og Danmark) tillater retningslinjene for hygiene at vasketemperaturene senkes, forutsatt at vaskemidlene som brukes, har den samme steriliserende virkningen (se side 16-17).

Det nordiske svanemerket for tekstiltjenester gir en omfattende oversikt over mulige forbedringer. Vær oppmerksom på at en vaskeritjeneste som er sertifisert etter det nordiske svanemerket, kanskje bare har gjennomført de viktigste miljøforbedringene (se del 4, side 22 for mer informasjon om dette).

Valg av fiber kan også ha betydning for påvirkningene fra vask, men dette dekkes ikke av det nordiske svanemerket (se del 5, side 24).
Alternativer for kassering er også ofte en aktuell problemstilling for miljøbeslutninger. Å sikre at en leverandør av tekstiltjenester gjenvinner tekstilene sine på slutten av levetiden, kan gi noen fordeler, men det er ikke like viktig for den totale miljøpåvirkningen som forlengelse av bruksfasen.

Det finnes en oversikt over miljøpåvirkninger i bakgrunnsdokumentet for tekstiler og bakgrunnsdokumentet for tekstiltjenester fra Sveriges nasjonale organisasjon for offentlige anskaffelser og i LCA-rapporten fra EUs Joint Research Centre. 


\section{Del 2}

\section{Innkjøpsprosessen, markedsdialog og innovasjon}

En innkjøpsprosess kan være svært kompleks og involverer en rekke trinn og strategiske beslutninger. Hvis det skal tas med miljøkriterier, bør dette besluttes $i$ den forberedende fasen, slik at man kan sikre at det stilles de riktige spørsmålene og tas de riktige beslutningene i rett tid.

En første beslutning å vurdere er hvorvidt man skal kjøpe inn produkter eller kjøpe inn funksjoner. Når produktgruppen er tekstiler, betyr det at det vil være relevant å vurdere om man skal kjøpe tekstiler eller kjøpe tilgang til tekstiler - det vil si leie.

Leie av tekstiler kan ha en positiv innvirkning på miljøpåvirkninger. Årsaken er at eierskapet til produktene forblir hos leverandøren, som vil ha økonomisk interesse av å sikre lang produktlevetid. Jo lenger et produkt er i bruk, jo lavere er miljøpåvirkningen, og jo mindre går det med av knappe ressurser.

Uansett om man beslutter å kjøpe eller å leie tekstiler og tekstiltjenester, er det viktig å konsultere markedet gjennom en innledende markedsdialog. Det er gjennom markedsdialogen du kan skaffe deg kunnskap om de tilgjengelige produktene og miljøegenskapene deres og om andre relevante, kvalitetsrelaterte aspekter (se eksempel på side 11).

En markedsdialog er en dialog mellom kunden og potensielle leverandører som gjennomføres før en formell anbudsprosess for å sikre at anbudsinnbydelsen er realistisk og gjenspeiler det som tilgjengelig $i$ markedet, men samtidig ambisiøs.

Det er mange måter å gjennomføre denne dialogen på, men det er viktig å huske på at den er tillatt frem til tidspunktet for publisering av anbudsinnbydelsen.
Etter publisering er det restriksjoner for dialog med potensielle leverandører.

Hva skal jeg spørre om i en markedsdialog? Det er mange aspekter som vil være relevante å ta opp, men i miljøperspektivet bør de følgende temaene drøftes:

- tilgjengelighet av miljømerkede produkter

- tilgjengelighet av økologiske, bomullsbaserte produkter

- bruk av alternative fibre

- opprinnelsen til tekstilfibre

- resirkulert innhold

- håndtering av kjemikalier, energi og vann i produksjonen

- egenskaper relatert til vask og vedlikehold

- egenskaper relatert til slitestyrke, inkludert om produktene kan repareres

- avtakbare logoer

- fargevalg og miljøkonsekvenser

- potensial ved slutten av levetiden (kan tekstilene resirkuleres?)

Det finnes mer inspirasjon til temaer å drøfte med markedet for å klargjøre hvilke miljøkriterier som kan benyttes, i EU-kommisjonens bakgrunnsdokument om kriterier for grønne offentlige anskaffelser av tekstiler. 


\section{NORSKE SYKEHUSINNKJØP: MARKEDET HJAELPER MED AT OPSTILLE REALISTISKE KRITERIER}

I 2014 kjøpte Sykehusinnkjøp HF (tidligere HINAS) inn tekstiler for helsesektoren og brukte en markedsdialogprosess til å definere egnede miljøkrav. Leverandørene ble oppfordret til å kommentere et utkast til kriterier som var kommet frem gjennom individuelle dialogmøter. Leverandørene ble invitert til disse møtene via en nettdatabase for offentlige anskaffelser.

Resultatet av markedsdialogen var at det skjedde en endring i innkjøpskravene fra $100 \%$ bomull til en mer slitesterk blanding av polyester og bomull. Leverandører anbefalte at innkjøpere ba om Oeko-Tex 100-merkede tekstiler, en merkeordning som riktignok er mindre streng enn miljømerker som det nordiske svanemerket og EU Ecolabel, men som kunne innfris av langt flere leverandører i 2014.

Sykehusinnkjøp HF gir følgende råd om markedsdialog for grønne innkjøp av tekstiler:

1. Benytt muligheten til å få markedet til å kommentere kriteriene dine og hjelpe deg å sikre at de er realistiske - men heller ikke uambisiøse.

2. Vurder å gjennomføre individuelle samtaler for å sikre at leverandørene kan snakke fritt, uten å hindres av at konkurrenter hører på.

3. Husk å la leverandørene utfordre innkjøpsvanene dine - inkludert ditt valg av fiber og av forretningsmodell.

Kontakt Evy Pleym på evy.pleym@sykehusinnkjop.no for mer informasjon. 
Den svenske organisasjonen for offentlige anskaffelser (Upphandlingsmyndigheten) tilbyr assistanse til offentlige organisasjoner i forbindelse med deres markedsdialoger. Assistansen omfatter møter og en arbeidssamling med organisasjonen. Se her. Organisasjonen er også i ferd med å skape et program for å utvikle nettressurser til hjelp i markedsdialoger. Ressursbanken på Internett omfatter foreløpig ikke ressurser relatert til tekstiler i helsevesenet.

På grunn av den raske utviklingen av nye teknologier/ metoder innen produksjon av tekstiler er det alltid viktig å gå inn i en markedsdialog. Det kan finnes muligheter til miljøforbedringer som sykehusinnkjøpere kanskje ikke er klar over. Det vil komme mange innovasjoner i produksjonsprosessen fremover som kan gi store miljø- og hygienemessige fordeler (se side 13).

Vær oppmerksom på at nyskapende teknologier noen ganger medfører en risiko for nye miljøproblemer, og at man derfor må kontrollere dem med tanke på dette før man tar dem i bruk.

Innkjøpere kan også sikre bruk av de nyeste innovasjonene gjennom signering av en utviklingskontrakt med leverandører: en langsiktig kontrakt med leverandørene som gjør at de kan ta i bruk nye teknologier etter hvert som de blir tilgjengelige, for å redusere miljøpåvirkningene ytterligere. Utviklingskontrakter kan bygge på funksjonelle kriterier (se boksen nedenfor).

\section{BRUK AV FUNKSJONELLE KRITERIER I ANBUDSDOKUMENTER}

For å gi rom for utvikling av nye produkter med mindre miljøpåvirkninger kan en innkjøpskontrakt baseres på funksjonelle krav i stedet for å spesifisere et gitt produkt.

Dette brukes mest for eksempel ved kjøp av energi- eller belysningstjenester, men kan også brukes for tekstiler i helsevesenet. En kontrakt kan for eksempel kreve levering av rent arbeidstøy til sykepleiere som er tilstrekkelig til å dekke et gitt antall sykepleierårsverk, og som oppfyller minimumsstandarder for hygiene, slitestyrke og komfort, men ikke kreve en bestemt fibertype. Deretter kan tjenesteleverandøren velge fibre som oppfyller disse standardene, og som har høyest slitestyrke, slik at leverandøren kan redusere kostnadene og miljøpåvirkningene sine.

Den svenske organisasjonen for offentlige anskaffelser har lagd en veiledning for definering av funksjonelle kriterier. Den finnes her. 


\section{EKSEMPLER PÅ LOVENDE INNOVASJONER}

\section{Tørrfarging}

Noen innovative selskaper har utviklet prosesser for tørrfarging. Et av dem bruker $\mathrm{CO}_{2}$ i stedet for vann og ingen tilsetning av prosesskjemikalier til å løse opp fargene. $\mathrm{CO}_{2}$-gassen kan dessuten gjenvinnes og brukes på nytt. Tørrfarging eliminerer spillvann som kan gi betydelige miljøpåvirkninger i produksjonsbedrifter. I tillegg eliminerer det behovet for å tørke tekstiler mellom prosesser, noe som gir energibesparelser.

\section{Biomimetikk}

Biomimetikk er anvendelse av naturens egen design på menneskeskapte produkter. Forskning på dette området har allerede ført til utvikling av tekstiler som etterligner flekkbestandigheten til lotusblader. Andre naturlige behandlinger har fokusert på å etterligne de antimikrobielle egenskapene til krabbe- og hummerskall. Tekstilanvendelser av disse teknologiene er allerede på fremmarsj og kan gi tekstiler som kan vaskes på lavere temperaturer, samtidig som man opprettholder høye hygienenivåer.

\section{Nanomaterialer}

Integrasjon av nanomaterialer i tekstilsubstrater kan øke slitestyrken til tekstilene og dermed redusere forbruk og kostnader. Nanomaterialer kan gjøre tekstilene flekkbestandige og krøllfri og eliminere statisk elektrisitet og elektrisk ledeevne i fibre uten at det går på bekostning av komfort eller fleksibilitet. 


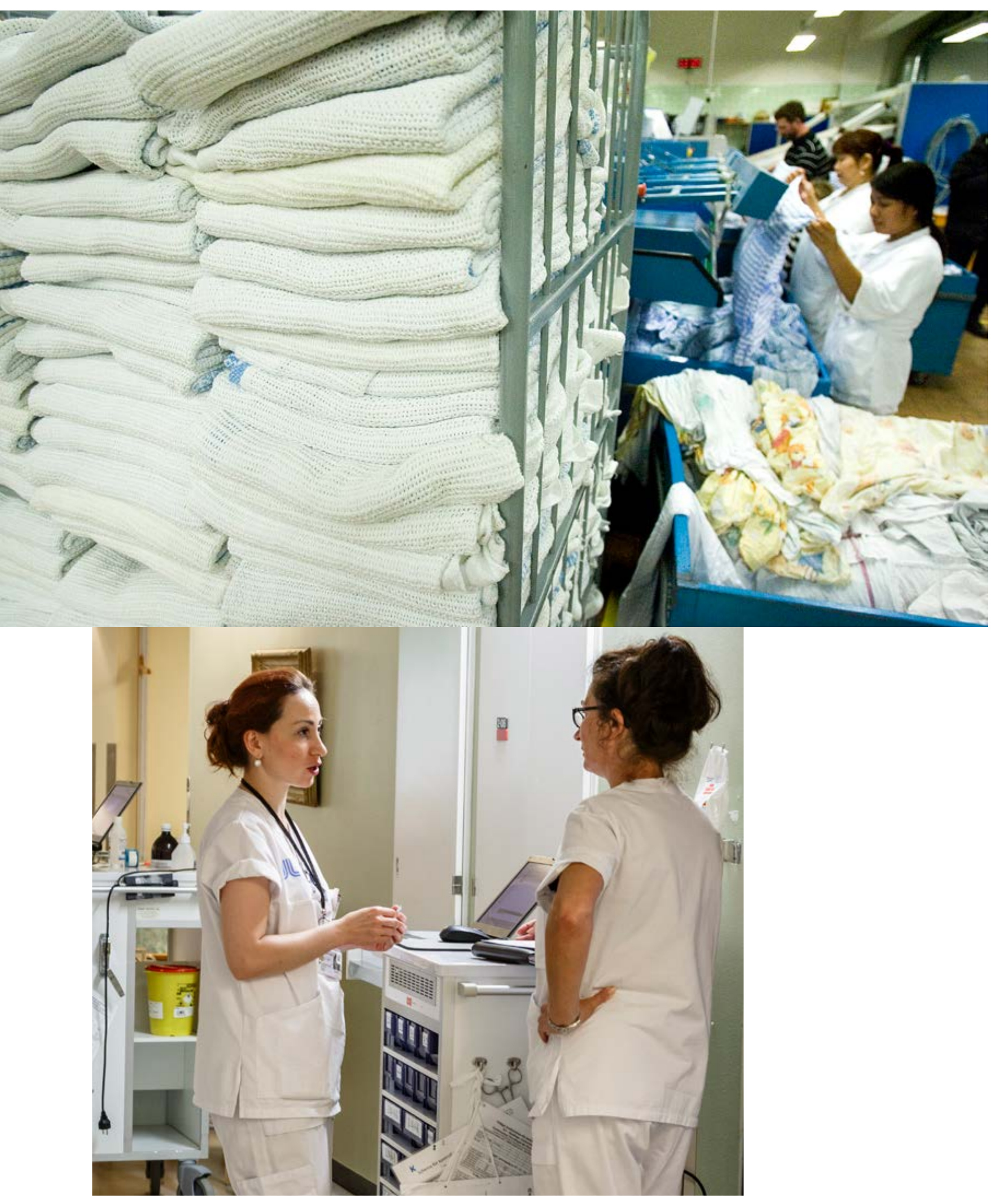




\title{
Del 3
}

\section{Lenker til nyttige dokumenter og ressurser}

\author{
Det finnes en rekke veiledninger som kan hjelpe innkjøpere å vurdere bærekraftighet \\ ved innkjøp av tekstiler og tekstiltjenester. Ingen av disse er spesifikke for tekstiler $i$ \\ helsesektoren.
}

EU: De EU-utviklede kriteriene for grønne offentlige anskaffelser (GPP) for

tekstiler, publisert i 2012, har følgende overordnede budskap:

Viktige miljøpåvirkninger

GPP-tilnærming

- Luftforurensning, ozondannelse (smog), bioakkumulering eller eksponering gjennom næringskjeden, skadelige virkninger på vannlevende organismer, økt vekst av uønskede vannlevende organismer som kan redusere vannkvaliteten, på grunn av feil bruk av bestemte plantevernmidler og gjødseltyper i produksjonen, og stoffer brukt i behandling av fibre og de ferdige tekstilproduktene

- Negativ innvirkning på arbeidshelsen til brukerne på grunn av rester av bestemte helseskadelige stoffer

- Unngåelse av kort levetid for produktet og dermed dårlig ressursutnyttelse ved å fremme bruk av fargeekte tekstiler som ikke krymper under bruk
- Kjøp økologisk produserte tekstiler.

- Kjøp brukte tekstiler som kan brukes på nytt til det opprinnelige formålet, eller kjøp tekstiler som inneholder resirkulerte fibre.

- Kjøp tekstiler produsert med redusert bruk av miljøfarlige stoffer.

- Kjøp tekstiler med mindre rester av helseskadelige stoffer.

- Kjøp tekstiler som oppfyller minimumskravene til fargeekthet og dimensjonsstabilitet.
Kriteriene inkluderer grunnleggende kriterier (minimumskriterier) og omfattende (mer ambisiøse) kriterier for

- rester av plantevernmidler i naturfiberprodukter

- rester av kjemikalier brukt i produksjonsprosesser

- restriksjoner på bruk av bestemte fargestoffer

- holdbarhet, for eksempel når det gjelder form og fargeekthet

Kriteriene omfatter også forslag til poenggivning for økologisk produksjon av naturfibre og andelen resirkulerte fibre i et produkt.

I GPP-kriteriene handler de fleste restriksjonene for farlige stoffer om rester i de ferdige produktene, ikke om bruk under produksjon. Unntaket er enkelte fargestoffer som GPP-kriteriene spesifikt forbyr i produksjon.
Uansett vil restriksjoner for rester av farlige kjemikalier i det ferdige produktet antagelig også føre til redusert bruk av dem i produksjonen. I tillegg vil det å gi poeng for å inkludere produkter av økologisk produsert bomull og andre naturfibre, redusere bruken av plantevernmidler.

GPP-kriteriene er generelt mindre strenge enn ofte brukte miljømerker, som det nordiske svanemerket og EU Ecolabel (se del 4, side 22). GPP-kriteriene er for øyeblikket under revisjon, og det forventes et revidert sett tidlig i 2017.

Nasjonalt: Nasjonale organisasjoner i noen av de nordiske landene bruker EU-kriteriene direkte som retningslinjer for innkjøpere av tekstiler, f.eks. i Norge, Danmark og Finland. 


\section{NASJONALE HYGIENESTANDARDER FOR VASKERIER I HELSESEKTOREN}

Ved defineringen av grønne innkjøpskriterier for vaskeritjenester må innkjøpere også ta hensyn til nasjonale retningslinjer for minimumsstandarder for hygiene for slike tjenester.

EU-standarden EN 14065 beskriver en metode for risikostyring for kontinuerlig sikring av den mikrobiologiske kvaliteten til vaskeribehandlede tekstiler. Denne standarden har blitt overført til tilsvarende nasjonale standarder. Standarden EN 14065 er nylig oppdatert. EU-standarden og de tilhørende nasjonale standardene finner du på disse lenkene: EU-standard, dansk versjon, svensk versjon, finsk versjon, norsk versjon.

Standarden EN 14065 tar for seg målterskler, kontroller og overvåkingssystemer for biokontaminasjon i ulike faser av vaskerisykluser snarere enn å definere vaskemetoder for å unngå biokontaminasjon.

Minst tre av de nordiske landene har imidlertid standarder eller retningslinjer som definerer metoder for vaskerier og vaskeritjenester som skal følges for å unngå biokontaminasjon.

- Dansk standard for håndtering av tekstiler til flergangsbruk i helsesektoren

- Svensk håndbok for tekstiler i helsevesenet

- Norsk standard for smittevern for vaskerier som behandler tekstiler til helseinstitusjoner 
Disse skiller seg fra hverandre når det gjelder krav til vasketemperatur for termisk desinfeksjon. Den norske standarden krever $85^{\circ} \mathrm{C}$ i ti minutter, den danske standarden minimum $80^{\circ} \mathrm{C}$ i ti minutter, og den svenske håndboken anbefaler minimum $70^{\circ} \mathrm{C}$ i ti minutter.

Både den norske og den danske standarden tillater lavere vasketemperaturer hvis vaskemidlene som brukes, har den samme steriliserende virkningen. Likeverdigheten må kontrolleres regelmessig. Ifølge en ledende leverandør av vaskeritjenester finnes det miljømerkede vaskemidler som oppfyller disse alternative kravene. Dette kan gi netto miljøgevinster sammenlignet med å sterilisere ved høye temperaturer.

Den svenske håndboken er en veiledning, ikke en obligatorisk standard. En vitenskapelig studie ved Uppsala universitetssykehus fant ut at reduksjon av temperaturer til $60^{\circ} \mathrm{C}$ ikke øker risikoen for biokontaminasjon, forutsatt at vaskingen etterfølges av tørking i tørketrommel ved mer enn $110^{\circ} \mathrm{C}$. Det reduserer det totale energiforbruket i vaskesyklusen (Tano og Melhus, 2014).*

*Tano, E, og Melhus, A. (2014) Level of decontamination after washing textiles at $60^{\circ} \mathrm{C}$ or $70^{\circ} \mathrm{C}$ followed by tumble drying. Infect Ecol Epidemiol. 2014 Nov 11;4:24314. 


\section{SAMFUNNSANSVAR (CSR) OG TEKSTILINNKJØP}

Samfunnsansvar (CSR - Corporate Social Responsibility) henviser til forretningspraksiser/forretningsskikk som omfatter tiltak som gagner samfunnet. Dette omfatter, i tillegg til miljøaspektene som er beskrevet i denne veiledningen, etiske arbeidspraksiser, motarbeidelse av korrupsjon og ivaretakelse av menneskerettigheter. Disse aspektene er relevante ved innkjøp av tekstiler til helsesektoren og har vært i fokus i enkelte nordiske land i mange år.

I Sverige har for eksempel alle regioner et felles sett med etiske regler som leverandører må signere på. Leverandørene må også redegjøre for sitt samsvar med reglene. De etiske reglene er basert på FNs menneskerettighetserklæring, de åtte grunnleggende konvensjonene til ILO (International Labour Organisation), FNs konvensjon om barns rettigheter, FNs konvensjon mot korrupsjon samt relevante lover om arbeidstakeres rettigheter og miljøbeskyttelse i produksjonslandet. De etiske reglene finnes her.

De svenske regionene har en felles nettportal med retningslinjer for og informasjon om samfunnsansvar, der tekstiler anses som ett av ni risikoområder ved innkjøp til helsevesenet. Utpekte regioner har ansvaret for samsvar og revisjoner for hver produktgruppe, og de siste årene har det for eksempel blitt kontrollert tekstilproduksjon i India og Pakistan. Risikovurderingen finnes her.

Den danske innkjøpsorganisasjonen har ytterligere etiske prinsipper og miljøprinsipper, som delvis består av FNs Global Compact-prinsipper.

Den norske organisasjonen, Avdeling for offentlige anskaffelser i Difi (ANS), tar også for seg etiske hensyn. Den fremmer tiltak rettet mot dårlige arbeidsforhold $i$ tekstilproduksjon: Better Cotton Initiative, Clean Clothes Campaign, ACCORD og IPEC. Blant disse er Better Cotton Initiative og ACCORD de nyttigste, siden man kan se hvilke varemerker/produsenter som er engasjert i tiltakene. Det er imidlertid (ennå) ikke noen garanti for at tekstiler produsert for disse medlemmene, er i samsvar med prinsippene eller målene for tiltakene.

EU Ecolabel, det nordiske svanemerket og Bra Miljöval omfatter kriterier som beskriver arbeideres rettigheter der produksjonen foregår (se del 4, side 22).

Andre nyttige lenker:

- World Wide Responsible Apparel

- CSR compass 
Sveriges nasjonale organisasjon for offentlige anskaffelser har en nettressurs som inneholder både retningslinjer og et omfattende bakgrunnsdokument som beskriver miljøpåvirkninger forårsaket av forbruket av tekstiler, forskrifter relevante for bruk av kjemikalier i tekstilproduksjon samt en liste over farlige kjemikalier som bør begrenses gjennom anbudskriterier. Kjemikalielisten er betydelig mer omfattende enn de ikke-bindende GPP-kriteriene til EU og ligger nær opptil de kjemikalierelaterte kriteriene i EU Ecolabel og det nordiske svanemerket for tekstiler.

I motsetning til andre organisasjoner har Sveriges nasjonale organisasjon for offentlige anskaffelser også et bakgrunnsdokument og retningslinjer for innkjøp av vaskeritjenester. Disse dekker en rekke problemstillinger i forbindelse med bruk og administrasjon av kjemikalier og vaskemidler i vaskeprosesser, energi- og vannforbruk i vaskeritjenester samt utslipp til luft fra vaskeritjenester.

EU-kriterier og nasjonalt foreslåtte kriterier for grønne offentlige anskaffelser kan alle oppfylles mer enn godt nok ved bruk av tekstiler som er sertifisert i henhold til det nordiske svanemerket, EU Ecolabel eller Bra Miljöval. De svenske kriteriene for vaskeritjenester kan på samme måte oppfylles gjennom tekstiltjenester som er sertifisert $\mathrm{i}$ henhold til det nordiske svanemerket (se del 4, side 22-24).

Boksen side 18 beskriver ressurser for inkludering av etiske kriterier i innkjøpsprosesser, men dette er ikke et fokusområde for denne veiledningen.

I siste instans må innkjøpere velge kriterier som er i overensstemmelse med behovene og de miljømessige (og etiske) ambisjonene. Side 20-21 inneholder et utvalg grunnleggende kriterier brukt av Sykehusinnkjøp HF, den sentrale innkjøperen i Norge, i en nylig anbudsinnbydelse for arbeidstøy. Anbudsinnbydelsen inneholdt også ytterligere kriterier relatert til slutten på levetiden for tekstiler som inneholder farlige kjemikalier, og kriterier relatert til emballering av produkter. Kriteriene er mindre omfattende enn EUs GPP-kriterier (Green Public Procurement - grønne offentlige anskaffelser).

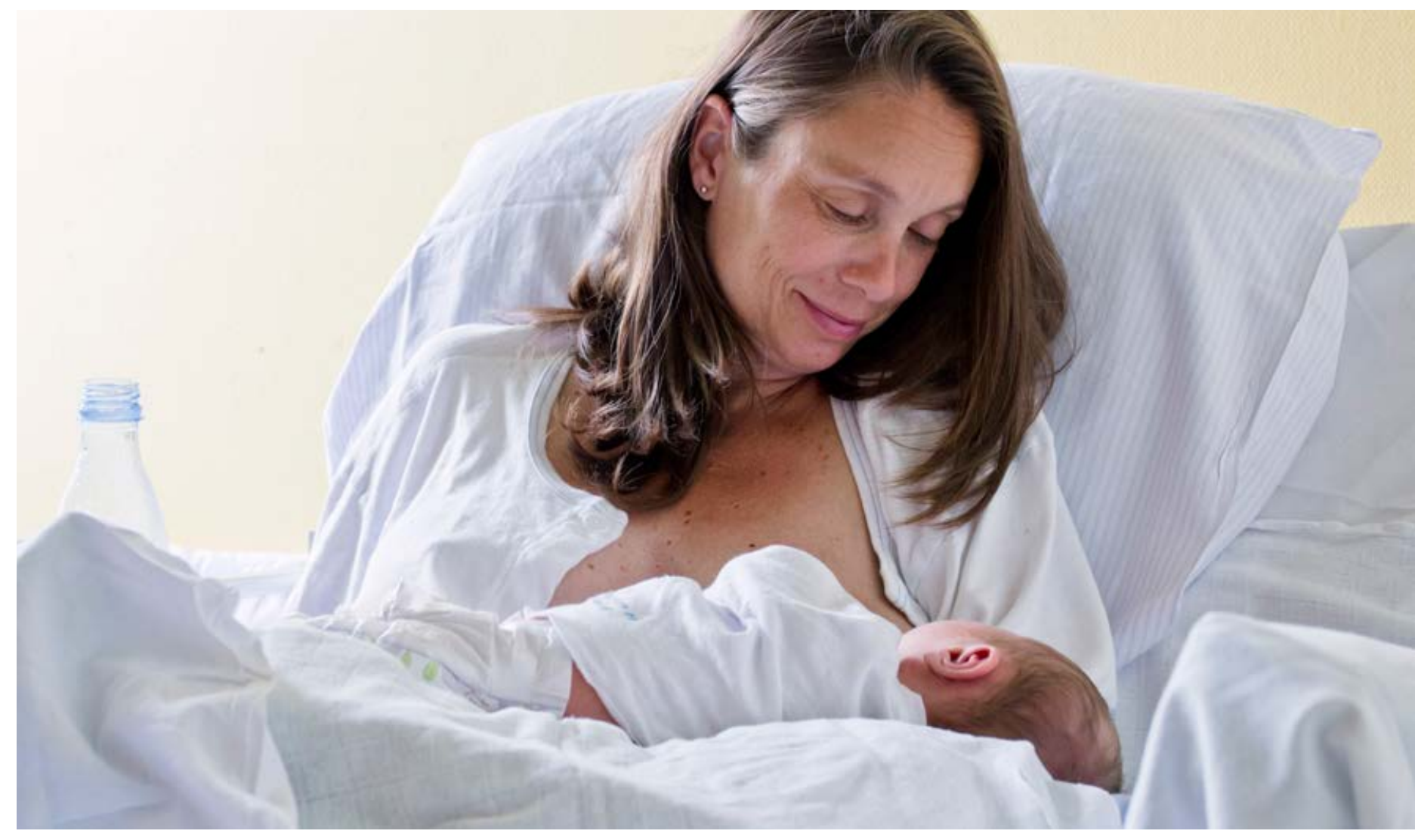




\section{Eksempel på kriterier brukt i en anbudsinnbydelse for arbeidstøy til personale}

\section{BASISKRAV KJEMIKALIER}

\section{1: Oppfyllelse av lovkrav}

De tilbudte artikler skal være i samsvar med krav som er gitt i forskrift om begrensning i bruk av helse- og miljøfarlige kjemikalier og andre produkter (Produktforskriften (FOR-2004-0601-922). De tilbudte artikler skal videre være i samsvar med krav som er gitt i kjemikalieregelverket REACH.

\section{Generelt krav:}

Produktene skal ikke inneholde stoffer på EUs kandidatliste eller den norske prioritetslisten. Dette gjelder også bruk av hjelpekjemikalier og vaskemidler.

\section{Bruk av Pesticider}

For produkter som er laget av bomull eller andre naturlige cellulosefibre, skal ikke sluttproduktet inneholde mer enn 0,05 ppm (milliontedel) av hvert av følgende stoffer. Det totale innhold av de følgende stoffer, skal ikke overstige 0,75 ppm:

- 2,4,5-T, Aldrin, Captafol, Klordan, Klordimeform, DDT, Dieldrin, Dinoseb med salter, Endrin, Heptaklor, Hexaklor- bensen, Hexaklorsyclohexan, $\alpha$, Hexaklorsyclohexan, $\beta$, Hexaklorsyclohexan, $\delta$, Metamidofos, Monokrotofos, Paration, Metylparation, Propethamphos, Toxafen

\section{Flammehemmere}

Det skal ikke finnes kjemiske flammehemmere i de anskaffede plaggene, bortsett fra der dette er helt nødvendig ut i fra de funksjoner tekstilene skal fylle. Dersom flammehemming er påkrevd, skal dette fremgå av konkurransegrunnlagets øvrige deler. Det skal i slike tilfeller benyttes fosforog/eller nitrogenbaserte organiske forbindelser, andre flammehemmere med tilsvarende eller bedre helse- og miljømessige egenskaper, eller velges flammeresistente tekstiler. Halogenerte flammehemmere skal ikke under noen omstendighet benyttes.

\section{Alkylfenoletoksilater}

Det skal ikke forefinnes alkylfenoletoksilater i produktet.

(Nonylfenol, et slikt stoff, er begrenset gjennom REACH vedlegg XVII (og prioritetsliste), men kan alikevel forekomme). 


\section{KRAVSPESIFIKASJON - (KVALITETSKRAV)}

\section{Dimensjonsendringer under vask og tørking}

Dimensjonsendringer etter vasking og tørking må ikke overstige:

+/- $3 \%$ for vevde produkter i bomull og bomullsmiks.

+/- $2 \%$ for vevde produkter av ullmiks og syntetiske fibre.

$+/-4 \%$ for strikkevarer.

+/- $6 \%$ for grovstrikk (Chunky knit).

$+/-5 \%$ for trikot (Interlock).

+/- $7 \%$ frottéhåndklær og finribbede produkter.

Kravet gjelder ikke for fibre eller garn, produkter som tydelig er merket "kun kjemisk rensing" eller tilsvarende (dersom produkt normalt merkes på denne måten).

Testene skal gjennomføres i henhold til EN ISO 6330, ISO 5077 eller tilsvarende. Følgende prosedyre skal følges ved testing: Vask tre ganger ved den temperatur som angis på produktet, med etterfølgende tørk i tørketrommel med mindre en annen torkeprosess er angitt på produktet.

\section{Fargeekthet ved vask (Vaskeekthet)}

Vaskektheten skal være minst nivå 3-4 for fargeforandring og minst nivå 3-4 for fargesmitte.

Kravet gjelder ikke for produkter som tydelig er merket "kun kjemisk rensing" eller tilsvarende (dersom produkt normalt merkes på denne måten) hvite produkter, eller produkter som verken er farget eller trykt. Testene skal gjennomføres i henhold til EN-ISO 105-CO6 eller tilsvarende. Dette vil si en enkelt vask ved den temperatur som er angitt på produktet.

\section{Våtgniding (Gniekthet, våt)}

Våtgnidning skal være minst nivå 2-3. Resultat 2 tillates for indigofarget denim. Kravet gjelder ikke for hvite produkter eller produkter som verken er farget eller trykt. Test skal gjennomføres i henhold til ISO 105 X12 eller tilsvarende.

\section{Tørrgnidning (Gniekthet, tørr)}

Fargebestandighet mot tørrgnidning skal være minst nivå 4. Nivå 3-4 tillates for indigofarget denim. Kravet gjelder ikke for hvite produkter, produkter som verken er farget eller trykt. Test skal gjennomføres i henhold til EN-ISO 105 X12 eller tilsvarende.

\section{TILDELINGSKRITERIER}

\section{Økologiske dyrket bomull eller andre naturlige fibre}

Det vil bli tildelt poeng etter hvor stor andel av produktene som er av økologisk dyrket bomull. Leverandøren skal i vektprosent angi hvor stor andel av sluttproduktet som består av økologisk dyrket bomull. For å bli betraktet som økologisk skal avlingene som fibrene stammer fra, være dyrket i overenstemmelse med Rådsforordning (EF) 834/2007 av 28.juni 2007 om økologisk produksjon og merking av økologiske produkter og om opphevelse av forordning (EØF) nr. 2092/91. 
Del 4

\title{
Kort oversikt over miljømerker
}

\author{
Å beslutte hvorvidt en anbudsinnbydelse skal omfatte et miljømerke, krever \\ grundige overveielser og kunnskap om hva hvert miljømerke omhandler. Du bør \\ velge et miljømerke som samsvarer med miljøambisjonene, men pass på ikke å \\ begrense gruppen av mulige leverandører for mye. Det kan også hende at ingen av \\ miljømerkene håndterer alle relevante miljøhensyn, og at du derfor kanskje ønsker å \\ ta med ytterligere kriterier.
}

Siden 2014 er det juridisk akseptabelt i EU å spesifisere miljømerker som kriterier direkte i en anbudsinnbydelse, men bare miljømerker som oppfyller bestemte rapport- og garantikrav (se del 3.5.1 i håndboken Buying Green!). Denne nye regelen gjør det enklere for innkjøpere å stille miljøbetingelser og enklere for leverandører å dokumentere at de oppfyller dem. I Danmark må innkjøpere imidlertid tillate leverandører med produkter som kanskje oppfyller betingelsene, men som ikke er sertifisert i henhold til et miljømerke. Leverandører må levere dokumentasjon på dette som kan leses på maksimum én time. Dette legger en ekstra byrde på innkjøperen.

Det finnes mange miljømerker for tekstilprodukter, men det er bare det nordiske svanemerket som har definert kriterier for tekstiltjenester. Relevante miljømerker for tekstiler til helsevesenet omfatter det nordiske svanemerket, EU Ecolabel (også kalt EU-blomsten), GOTS (Global Organic Textile Standard) og det svenske Bra Miljöval. Oeko-Tex 100merket er strengt tatt ikke et miljømerke, men det spesifiseres innimellom i kriterier for grønne innkjøp. BlueSign-merket brukes egentlig fremdeles bare for utendørsprodukter og er derfor (ennå) ikke relevant for sykehusinnkjøpere, med arbeidsklær til utendørsbruk som et mulig unntak.

Vær klar over at ikke alle miljømerker samsvarer med kriteriene som er definert av EU-kommisjonen i håndboken Buying Green!, som tillater at de brukes i anbudsinnbydelser.
Tabellen nedenfor gir en kort sammenligning av miljøspørsmålene som de mest relevante miljømerkene omhandler. To haker betyr strengere og/ eller mer omfattende kriterier enn én hake.

Det er også utført en sammenligning mellom de samme miljømerkene med hensyn til restriksjoner for bestemte kjemikalier og stoffer av den svenske organisasjonen for offentlige anskaffelser. Den finnes her.

Formålet med Oeko-Tex-merket er å beskytte brukere av tekstiler mot rester av farlige kjemikalier i klær og andre tekstiler som selges. Restriksjoner for kjemikalier under de andre miljømerkene gjelder for hele livssyklusen og har som mål å redusere innvirkningen på økosystemer og mennesker i hele verdikjeden, inkludert sluttbrukeren. Oeko-Tex har introdusert et merke (STeP) som dekker miljøaspekter ved produksjon, men dette er en type merke for miljøhåndtering for produksjonssteder, ikke et produktmerke. Det har derfor begrenset relevans for innkjøpere.

Det nordiske svanemerket finnes også i en versjon som dekker tekstiltjenester. Dette merket omfatter spesielle kriterier for vask av sykehustekstiler for å ta høyde for hygienestandarder. Kriteriene omhandler bruk av energi, vann og vaskemidler i vaskerier samt emballering og bruk av transport i logistikk. Merket omfatter også krav til en minimumsandel av økologisk merkede tekstiler $\mathrm{i}$ tekstilene som leies ut av tekstiltjenesten. 
Kort sammenligning av miljømerker for tekstilprodukter

\begin{tabular}{|c|c|c|c|c|c|}
\hline & $\begin{array}{l}\text { Det nordiske } \\
\text { svanemerket }\end{array}$ & $\begin{array}{l}\text { EU } \\
\text { Ecolabel }\end{array}$ & Bra Miljöval & $\begin{array}{l}\text { GOTS (bare } \\
\text { naturfibre) }\end{array}$ & $\begin{array}{l}\text { Oeko-tex } \\
100\end{array}$ \\
\hline $\begin{array}{l}\varnothing \text { kologisk andel } \\
\text { (naturfibre) }\end{array}$ & $\checkmark$ & $\checkmark$ & $\checkmark \checkmark$ & $\checkmark \checkmark$ & \\
\hline Resirkulert innhold & $\checkmark$ & $\checkmark$ & $\checkmark$ & & \\
\hline $\begin{array}{l}\text { Kjemiske restriksjoner } \\
\text { for produksjons- } \\
\text { prosesser }\end{array}$ & $\checkmark \checkmark$ & $\checkmark \checkmark$ & $\checkmark \checkmark$ & $\checkmark \checkmark$ & \\
\hline $\begin{array}{l}\text { Restriksjoner for kjemi- } \\
\text { kalierester i produkt }\end{array}$ & $\checkmark \checkmark$ & $\checkmark \checkmark$ & & $\checkmark \checkmark$ & $\checkmark \checkmark$ \\
\hline $\begin{array}{l}\text { Behandling av } \\
\text { avløpsvann }\end{array}$ & $\checkmark \checkmark$ & $\checkmark \checkmark$ & $\checkmark \checkmark$ & $\checkmark \checkmark$ & \\
\hline $\begin{array}{l}\text { Redusert } \\
\text { luftforurensning }\end{array}$ & & $\checkmark$ & $\checkmark \checkmark$ & & \\
\hline Redusert fast avfall & & & $\checkmark$ & $\checkmark$ & \\
\hline $\begin{array}{l}\text { Produktkvalitet og } \\
\text {-holdbarhet }\end{array}$ & $\checkmark$ & $\checkmark$ & & $\checkmark$ & \\
\hline Emballasje & $\checkmark$ & & $\checkmark \checkmark$ & $\checkmark \checkmark$ & \\
\hline $\begin{array}{l}\text { Arbeiderrettigheter/ } \\
\text { arbeidsforhold }\end{array}$ & $\checkmark \checkmark$ & $\checkmark \checkmark$ & $\checkmark \checkmark$ & & \\
\hline $\begin{array}{l}\text { Sertifisering } \checkmark \checkmark 3 \text {. part } \\
\checkmark 2 \text {. part }\end{array}$ & $\checkmark \checkmark$ & $\checkmark \checkmark$ & $\checkmark \checkmark$ & $\checkmark \checkmark$ & $\checkmark \checkmark$ \\
\hline
\end{tabular}

Kilde: Sammenligning foretaget af Planmiljø

Som innkjøper ønsker du kanskje å vurdere ytterligere kriterier. Kriteriene i miljømerker kan gi inspirasjon til dette. En leverandør av tekstiltjenester kan for eksempel sertifiseres i henhold til det nordiske svanemerket hvis den oppfyller minimumskriteriene og i tillegg får 15 av 65 mulige poeng i tilleggskriteriene. En mer ambisiøs innkjøper vil kanskje øke terskelen for eksempel til 25 poeng for tilleggskriteriene som tjenesteleverandører må oppfylle.

Før du bruker miljømerker i en anbudsinnbydelse, må du forsikre deg om at minst to eller tre leverandører kan oppfylle kravene. I motsatt fall kan det ende med at du må betale en pris som ikke er konkurransedyktig. De fleste miljømerker har en liste over produkter som er sertifisert i ulike kategorier. Det vil også være til hjelp i markedsdialogen (se del 2, side 10-12).

Kriteriene for de ulike miljømerkene finnes her:

- Svanemerket, tekstiler.

- Svanemerket, tekstiltjenester.

- EU Ecolabel, tekstiler.

- Bra Miljöval.

- GOTS.

- Oeko-Tex 100. 
Del 5

\section{Valg av fiber}

Valg av den riktige fiberen kan gi betydelige miljøfordeler på alle slags måter. Fibervalget

kan for eksempel påvirke energiforbruket under vask, slitestyrken til produktet og

miljøpåvirkningene fra produksjonen. Det er også viktig for komfort og hygiene.

Når du velger tekstilfiberen, er det viktig å vurdere egenskapene og miljøpåvirkningene. For eksempel:

- Ulike fibre har ulike miljøprofiler under produksjon. Diagrammet nedenfor er utviklet ved hjelp av metoder for livsløpsanalyse (LCA - Life Cycle Assessment). Bomull og polyester har som regel større miljøpåvirkninger under produksjon enn en del fibertyper som er på vei inn på markedet. Diagrammet omfatter ikke toksisitetsvirkninger, som ville ha stilt bomull i et litt verre lys på grunn av det høye forbruket av plantevernmidler $\mathrm{i}$ konvensjonell bomullsdyrking. Disse kan reduseres ved bruk av økologisk bomull.

- Noen fibre er mer slitesterke enn andre. Polyester eller en blanding av polyester og bomull tåler flere vaskesykluser enn $100 \%$ bomull ${ }^{3}$. Tilføyelse av en lettstelt overflate kan også øke levetiden.

\section{- Syntetiske fibre er enklere å vaske. Siden de} absorberer mindre vann, går det med mindre strøm til å tørke dem i tørketrommel. Nye studier viser også at de kan vaskes ved lavere temperaturer enn bomull uten at det går på bekostning av hygiene, selv om dette ikke er anerkjent i gjeldende nasjonale hygienestandarder.

\section{- Rene fibre og syntetiske stoffer er enklere å} resirkulere etter bruk. $100 \%$ polyester kan teoretisk resirkuleres til nye tekstiler i det vendelige. $100 \%$ bomull kan også resirkuleres til bruk i nye tekstiler, men den må blandes med $80 \%$ ny bomull for å opprettholde tekstilkvaliteten. Det er vanskeligere å resirkulere fiberblandinger, f.eks. polyester/bomull. Svært viktig: Ingen sykehusstrategi for resirkulering må gå ut over slitestyrken. Lengre levetid gir langt større miljøfordeler enn resirkulering.

\section{- Syntetiske fibre kan føre til mikroplastforurensning} av havene, men er en svært liten kilde for eksempel sammenlignet med bildekk. Det forventes at dette problemet kan løses i fremtiden gjennom utvikling av spesielle filtre for avløpsvann fra vaskerier ${ }^{4}$.

${ }^{3}$ http://www.howstuffcompares.com/doc/c/cotton-vs-polyester.htm

${ }^{4}$ http://www.plasticsouplab.org/showcases/washing-machine-filter/ 
Sammenligning af livscykluspåvirkninger fra forskellige fibre

\begin{tabular}{|c|c|c|c|c|c|}
\hline & Energy use & Water use & $\begin{array}{l}\text { Greenhouse } \\
\text { gasses }\end{array}$ & Waste water & $\begin{array}{l}\text { Direct land } \\
\text { use }\end{array}$ \\
\hline $\begin{array}{l}\text { Decreasing } \\
\text { environment al } \\
\text { impact }\end{array}$ & $\begin{array}{l}\text { Acrylic } \\
\text { Nylon } \\
\text { Polyester/ } \\
\text { PTT } \\
\text { Regen. } \\
\text { cellulosic } \\
\text { (viscose, } \\
\text { Modal) } \\
\text { PLA/ } \\
\text { Cotton/ } \\
\text { Lyocell } \\
\text { Wool } \\
\text { Natural } \\
\text { bast fibres } \\
\text { (nettle, } \\
\text { hemp, flax) }\end{array}$ & $\begin{array}{l}\text { Cotton } \\
\text { Silk } \\
\text { Nylon } \\
\text { Regen. } \\
\text { cellulosic } \\
\text { Acryl } \\
\text { Hemp } \\
\text { Wool } \\
\text { Natural bast } \\
\text { fibres } \\
\text { Polyester }\end{array}$ & $\begin{array}{l}\text { Nylon } \\
\text { Polyester } \\
\text { Lyocell } \\
\text { PLA } \\
\text { Viscose } \\
\text { Modal } \\
\text { Cotton } \\
\text { Natural bast } \\
\text { fibres } \\
\text { Wool }\end{array}$ & $\begin{array}{l}\text { Wool } \\
\text { Regen. } \\
\text { cellulosic } \\
\text { Natural bast } \\
\text { fibres } \\
\text { Nylon } \\
\text { Polyester }\end{array}$ & $\begin{array}{l}\text { Wool } \\
\text { Ramie } \\
\text { Cotton } \\
\text { Flax } \\
\text { Hemp } \\
\text { Viscose } \\
\text { and Modal } \\
\text { Jute } \\
\text { PLA } \\
\text { Lyocell }\end{array}$ \\
\hline
\end{tabular}

Kilde: EUs tekniske bakgrunnsrapport for GPP-kriterier for tekstiler fra 2011

Fiberen som brukes, må også oppfylle andre krav, ikke minst hygienestandarder (for eksempel smittekontroll for tekstiler i operasjonsstuer, se del 6, side 28-29) og krav til brukerkomfort.

\section{Komfort: Er bomull egentlig best?}

Til tross for de miljømessige ulempene kan bomull være den foretrukne fiberen med hensyn til komfort for sykehuspersonell og pasienter. Dette kan imidlertid være basert på forutinntatte holdninger snarere enn faktisk erfaring.

Det finnes laboratorietester for komfort som bruker standard testteknikker til å måle:
- termisk bestandighet

- bestandighet mot vanndamp

- luftgjennomtrengelighet

- overflatefriksjon og -grovhet (Kawabatavurderingssystemet)

- fuktighetshåndtering (AATCC-standard)

- strekkstyrke

For å bryte ned forutinntatte holdninger kan det være hensiktsmessig å gjennomføre en brukertest av tilgjengelige tekstilalternativer blant personale og pasienter før det tas en endelig beslutning. Brukertesting kan avdekke at alternative fibre som gir miljømessige og økonomiske fordeler, er mer enn komfortable nok for brukerne ${ }^{5}$. Se boksen på side 26 for et eksempel på et pilotprosjekt som ga akkurat det resultatet.

${ }^{5}$ http://www.greenercleaner.net/natural-or-synthetic-textiles/ 


\section{INNOVATIVE INNKJØP AV ARBEIDSTØY VED SYKEHUSET I RAWICZ}

I 2011 sluttet sykehuset i Rawicz i Polen seg til The Low Carbon Building (LCB) -

Healthcare network, et EU-finansiert nettverk for innovative innkjøp. Det ble satt i gang et pilotprosjekt for innovative innkjøp ved sykehuset som fokuserte på mer bærekraftige innkjøp av arbeidstøy til personalet.

Pilotprosjektet startet med at man snakket med sykepleiere, leger og annet personale om de viktigste funksjonelle egenskapene til arbeidstøy. Det viste seg å bli en nyttig erfaring for personalet, som førte til følgende prioriteringer: Det nye arbeidstøyet måtte være funksjonelt, tiltalende, brukervennlig, enkelt å rengjøre, slitesterkt og kostnadseffektivt.

Spesifisering av disse funksjonelle resultatene i stedet for spesifisering av materiale, fibertype, utforming osv. i anbudsdokumenter ga innkjøpere og leverandører mulighet til å utforske mer innovative løsninger. Siden pilotprosjektet vekket interesse hos åtte andre sykehus i Polen, kunne man dessuten tiltrekke seg et bredt spekter av leverandører som ønsket å utvikle tilbud.

Sykehuset kommuniserte proaktivt sine behov og markedskrav, og det ble avholdt et åpent møte med potensielle leverandører. Tilbakemeldingene var svært positive, og de åpne spesifikasjonene ga leverandørene mulighet til å differensiere produktene sine basert på andre faktorer enn pris. Spesielt ble det gitt forrang til livsløpskostnader (TCO - Total Cost of Ownership, se del 7, side 30-31) fremfor innkjøpskostnader ved vurdering av tilbud fra leverandører.

Resultatet av markedsdialogen og anbudsprosessen var at arbeidstøy ble fremstilt av en blanding av polyester og Tencel (et eukalyptusbasert produkt). Man fant ut at materialblandingen var like robust i vaskeprosessen, raskere å tørke og mindre utsatt for flekker, og det fikk generell anerkjennelse for kvalitet og funksjonalitet. Selv om innkjøpsprisen var høyere enn enkelte konkurrerende anbud, hadde arbeidstøyet de laveste livsløpskostnadene på grunn av reduserte vaskeutgifter og lengre levetid.

Kontakt Marcin Kautsch for mer informasjon. E-post: mxkautsc@wp.pl 


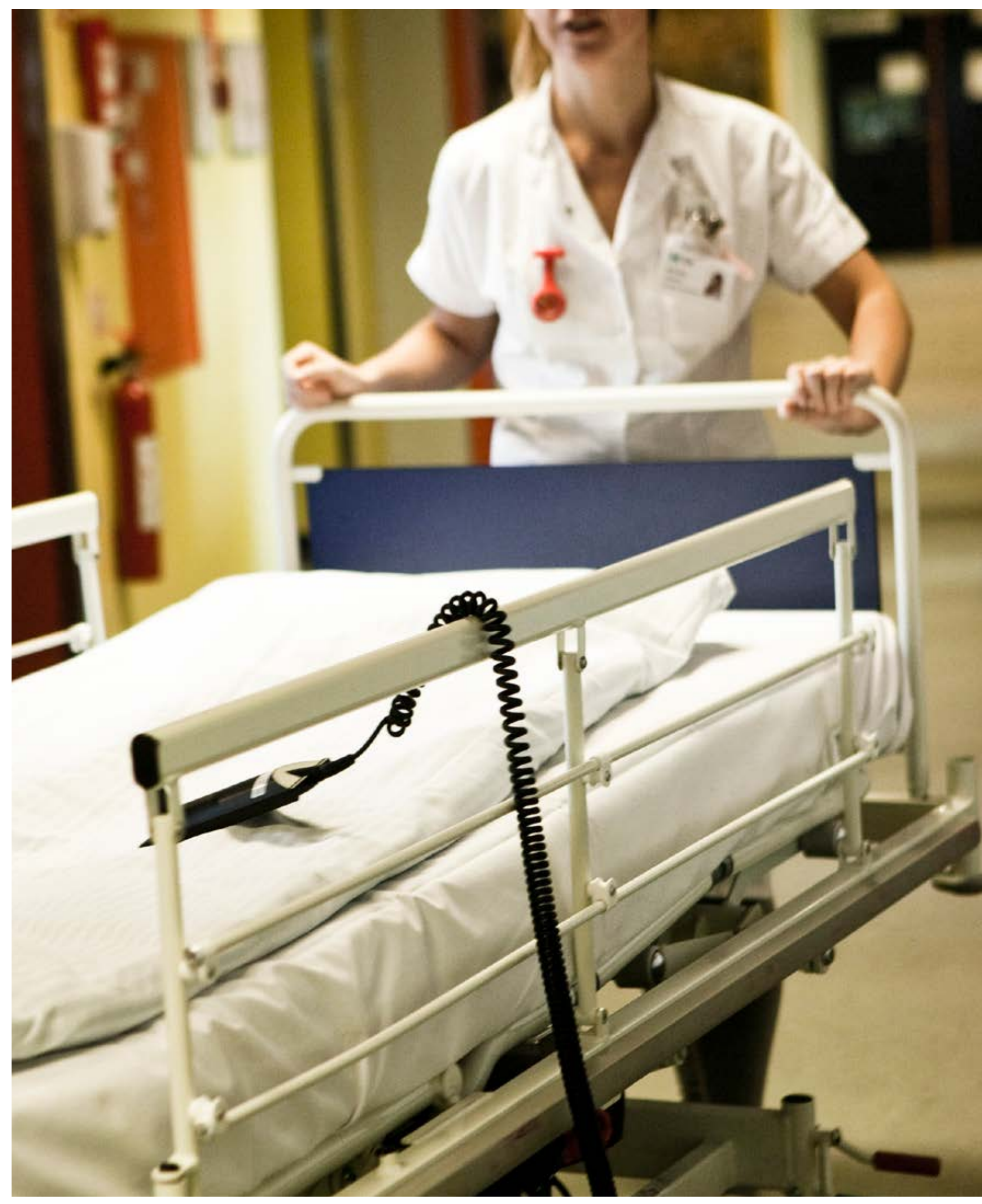


Del 6

\title{
Tekstiler til engangsbruk kontra tekstiler til flergangsbruk
}

\author{
Det er fordeler og ulemper både ved ikke-vevde tekstilprodukter til engangsbruk \\ og tekstilprodukter til flergangsbruk. Det gjelder spesielt for operasjonsstuer, der \\ smittekontroll har avgjørende betydning. I tillegg til hygiene er viktige variabler total \\ kostnad per bruk, funksjonalitet, komfort og - spesielt viktig i denne sammenhengen - \\ miljøhensyn.
}

Tekstiler til engangsbruk og moderne tekstiler til flergangsbruk på operasjonsstuer er mer eller mindre identiske med hensyn til barrierevern, som er en kritisk faktor for smittekontroll. Dette avhenger av at tekstiler til flergangsbruk vaskes og steriliseres i henhold til godkjente prosedyrer etter hver bruk.

Minimal avgivelse av luftbårne partikler er også viktig for smittekontroll. Moderne barrieretekstiler til flergangsbruk fremstilt av sammenhengende fibre har mye mindre potensial for å avgi lo enn tradisjonelle bomullstekstiler og fungerer like godt som ikke-vevde produkter til engangsbruk. De er også komfortable og har god pusteevne.

Resultater fra studier er tvetydige med hensyn til kostnad per bruk for produkter til engangsbruk kontra produkter til flergangsbruk, og sammenligningen vil være svært landspesifikk. Høyere arbeidskostnader kan tale for produkter til engangsbruk, mens høye avfallskostnader kan gjøre produkter til flergangsbruk mer kostnadseffektive.
På den andre siden viser en rekke studier at tekstiler til flergangsbruk gir betydelige miljøfordeler sammenlignet med tekstiler til engangsbruk $k^{6,7,8,9}$. En gjennomgang av seks studier av livssyklus avdekket at tekstiler til engangsbruk gir to til tre ganger så stort karbonavtrykk, energiforbruk og vannforbruk per bruk i operasjonsstuen som moderne tekstiler til flergangsbruk $^{10}$. Siden moderne tekstiler til flergangsbruk er bedre enn eller sammenlignbare med tekstiler til engangsbruk på andre områder, ser det ut til at de er et mer bærekraftig valg.

\section{Sammenligning av tekstiler til engangsbruk og tekstiler til flergangsbruk på operasjonsstuer} Bruk av tekstiler til flergangsbruk på operasjonsstuer forutsetter at sykehuset har kapasitet til å sterilisere operasjonspakker til gjenbruk.

De følgende rådene er rettet mot sykehus og deres leverandører av vaskeritjenester som ønsker å gå over fra tekstiler til engangsbruk til tekstiler til flergangsbruk for operasjonsstuer ${ }^{11}$ :

\footnotetext{
${ }^{6}$ Overcash (2012) A Comparison of Reusable and Disposable Perioperative Textiles: Sustainability State-of-the-Art 2012 http://www.ncbi.nlm.nih.gov/pubmed/22492184

${ }^{7}$ Carre (2008) LCA Comparing Laundered Surgical Gowns with Polypropylene Based Disposable Gowns http://trlaa.com.au/wordpress/wp-content/uploads/Lifecycle_Assessment_Study.pdf

${ }^{8}$ Mikusinska (2012) Comparative Life Cycle Assessment of Surgical Scrub Suits

http://kth.diva-portal.org/smash/get/diva2:574013/FULLTEXT01.pdf

${ }^{9}$ Eriksson och Berg (2003) Livscykelanalys av Operationsrockar

http://www.vgregion.se/upload/Tv\%C3\%A4tteriet\%20Alings\%C3\%A5s/LCA\%2Ooperationsrockar_granskad.pdf

${ }^{10}$ Overcash (2012) A Comparison of Reusable and Disposable Perioperative Textiles: Sustainability State-of-the-Art 2012 http://www.ncbi.nlm.nih.gov/pubmed/22492184

${ }^{11} \mathrm{https} / / /$ mericanlaundrynews.com/articles/winning-sale-reusable-surgical-textiles-part-1
} 


\begin{tabular}{|l|c|c|c|}
\hline & Cotton reusable & Disposables & High tech reusable \\
\hline Barrier effect & - & + & + \\
\hline Cleanliness & + & $?$ & + \\
\hline Particle emission & - & - & + \\
\hline $\begin{array}{l}\text { Comfort and } \\
\text { breathability }\end{array}$ & + & - & + \\
\hline Environmental impact & $+/-$ & + & + \\
\hline Functionality & - & $+/-$ & $+/-$ \\
\hline Cost effective & $+/-$ & $+/-$ & + \\
\hline Value for money & - & & + \\
\hline
\end{tabular}

Kilde: Petel, M. (2014) $)^{12}$

1. Begynn i det små. Begynn med en håndterbar plan, for eksempel operasjonshåndklær og operasjonsfrakker.

2. Samarbeid med leverandøren av operasjonsromutstyr til flergangsbruk. Utnytt kunnskapen og ressursene som leverandøren kan bidra med. Kontakt vaskerier som har lyktes med å innføre programmer for gjenbruk på operasjonsstuer.

3. Lag en skisse som sammenligner produkter til engangsbruk med produkter til flergangsbruk. Denne sammenligningen bør omfatte kostnader, produkt- og barriereegenskaper, sterilisering, avfallskostnader, levering, personellbehov og andre tjenester som vaskeriet kan levere.

4. Opprett er tverrfaglig team når du har fått innledende aksept.
5. Gi teamet (miljøledere, klinisk personell og beslutningstakere) en omvisning i vaskeriet og lagerrommet.

6. Gjennomfør en produktutprøving over noen uker. Noen er kanskje motstandere av gjenbruksprogrammet, men la dem få prøve det.

7. Lag en tydelig prosess for gjennomføring av omleggingen (en som bruker opp lageret av engangsprodukter osv.).

8. Fortsett med å gi støtte til og lære opp personalet og vurdere og måle resultater. 


\title{
Del 7
}

\section{Bruke livsløpskostnader}

\author{
Livsløpskostnader (TCO - Total cost of Ownership) omfatter kostnadene knyttet til \\ et produkt gjennom hele levetiden, fra innkjøp til slutten av levetiden. $\AA$ ta beslutnin- \\ ger basert på livsløpskostnader i stedet for innkjøpspris kan gi miljøfordeler.
}

Det billigste tekstilproduktet er ofte ikke det mest miljøvennlige. Når livsløpskostnadene for et produkt beregnes, kan det være bedre samsvar mellom miljøgevinster og budsjetthåndtering. Det vil spesielt være tilfellet for mer slitesterke tekstiler, som vil spare både penger og miljøressurser, selv om de kanskje koster mer å anskaffe. Valget mellom tekstiler til engangsbruk og tekstiler til flergangsbruk (se del 6, side 28-29) kan også bli enklere etter beregning av livsløpskostnadene, eller TCO.

Livsløpskostnader omfatter kostnadene knyttet til et produkt gjennom hele levetiden, fra innkjøp til slutten av levetiden. Livsløpskostnader gir et rammeverk og et språk for å beskrive og måle bærekraftpåvirkninger på en måte som er enkel å forstå for innkjøpsledere. Livsløpskostnader kan for eksempel brukes $\mathrm{i}$ kombinasjon med livssyklusanalyse (LCA - Life Cycle Assessment) og lignende metoder for å avdekke (og kommunisere) muligheter både til besparelser og bærekraftfordeler for faktorer som energi- og vanneffektivitet.

Bruk av livsløpskostnader krever kunnskap om faktorene som må tas med $i$ beregningene, og god oversikt over hvordan produktet brukes. For tekstilprodukter i helsesektoren omfatter dette kunnskap om:
- innledende pris

- antall brukssykluser før produktet er utslitt

- energi- og vannforbruk og andre kostnader knyttet til vask

- behovet for og kostnader ved reparasjoner

- kostnader ved kassering

Du kan bruke livsløpskostnader til å velge mellom leverandører av tekstiler (se eksempelet fra sykehuset i Rawicz på side 28). Husk å få leverandører til å dokumentere slitestyrken (antall brukssyskluser før kassering) til tekstilene sine, siden det er en viktig faktor for livsløpskostnader. Få hvis mulig med en klausul i kontrakten som binder dem til denne spesifikasjonen.

De fleste store leverandører av tekstiltjenester har beregnet livsløpskostnader som hjelp til å minimere kostnader, og vil kanskje kunne utføre disse beregningene for deg. Det samme kan være tilfellet med nasjonale innkjøpere, for eksempel Sykehusinnkjøp HF i Norge. For innkjøpere på regionalt nivå, kommunenivå eller sykehusnivå kan det imidlertid være for ressurskrevende å utvikle modeller for beregning av livsløpskostnader for alle produkter de kjøper inn, inkludert tekstiler.

Det finnes en rekke verktøy og tips å støtte seg til ved vurdering av livsløpskostnader, men for øyeblikket finnes det ingen modeller for beregning av livsløpskostnader for tekstilprodukter i helsesektoren. Her finner du flere verktøy og mer generell informasjon: 


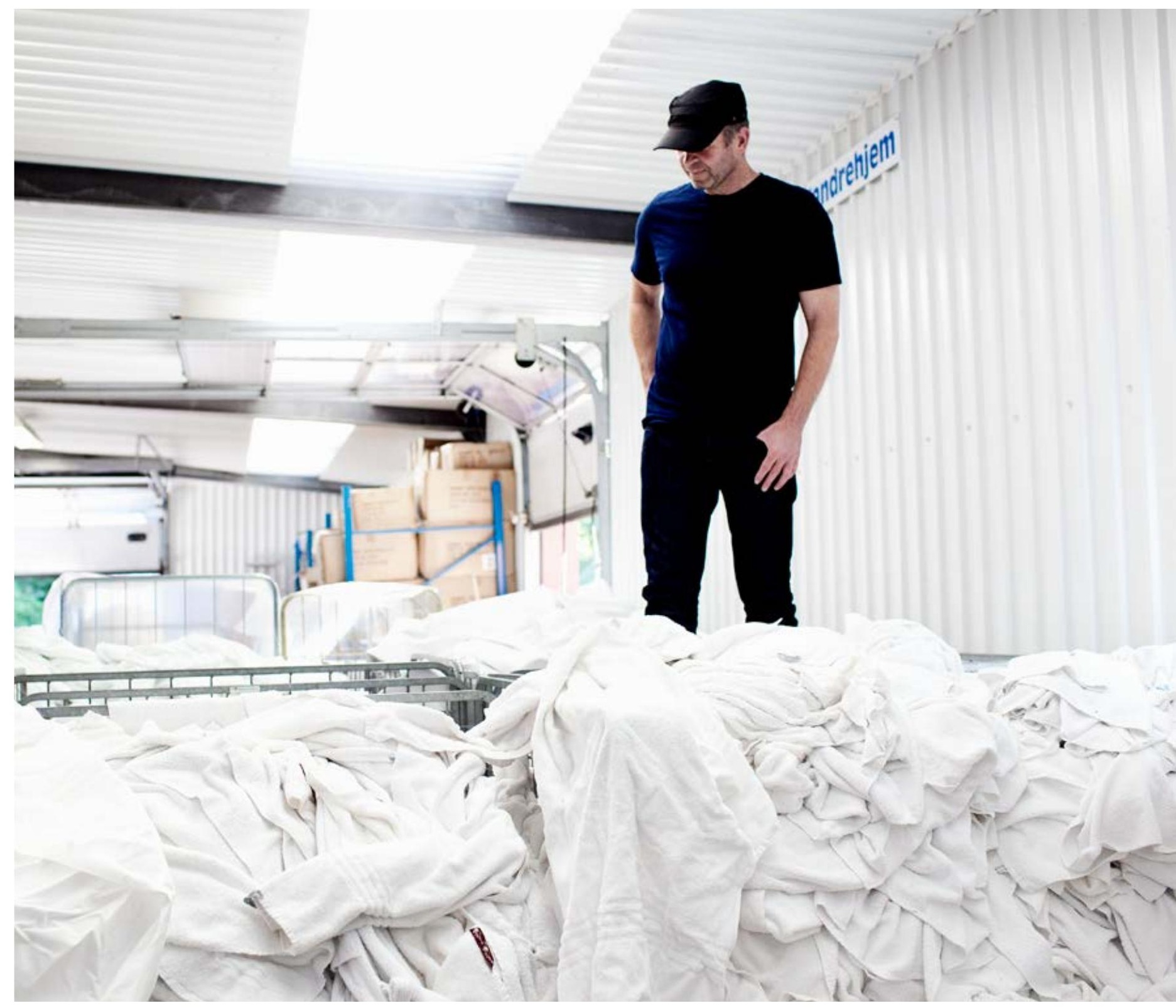

- Det danske forumet for bærekraftige innkjøp - et nasjonalt nettverk/forum for deling av kunnskap der innkjøpere både fra offentlige og private organisasjoner kan holde seg oppdatert om beste praksiser, metoder og verktøy for grønne innkjøp, inkludert verktøy for beregning av livsløpskostnader (dansk).
- Den ansvarlige innkjøperen - et nettsted der innkjøpere kan finne grønne kriterier som er klare til å kopieres og limes inn i anbudsdokumenter for en rekke produktområder, og verktøy for beregning av livsløpskostnader for utvalgte produktområder (dansk).

- BSR (Business for Social Responsibility (om samfunnsansvar)) (engelsk). 
Del 8

\title{
Om veiledningen og nettverket bak
}

\author{
Denne veiledningen er utviklet som et ledd $i$ et tiltak $i$ den nordiske handlingsplanen \\ for bærekraftige moteartikler og tekstiler med navnet "Well-dressed in a Clean \\ Environment» ("Velkledd $i$ et rent miljø»), finansiert av Nordisk ministerråd.
}

Den nordiske handlingsplanen definerer grønne offentlige anskaffelser som et svært viktig moment. For det første fordi offentlig sektor er en betydelig forbruker av tekstiler - med en verdi på ti milliarder euro per år på EU-nivå . For det andre kan grønne offentlige anskaffelser føre til etablering av markeder og prosesser som kan ha positive bivirkninger og inspirere private innkjøpere til å følge etter.

Denne veiledningen er utviklet i samarbeid med et nordisk nettverk av innkjøpere i helsesektoren. Nettverket ble startet av den danske Miljøstyrelsen på vegne av Nordisk ministerråd. PlanMiljø ApS og TEM har bistått i prosessen ved å tilrettelegge for nettverket og skissere veiledningen. Nettverket har følgende medlemmer:

Christian Leth Christensen, Region Midt-Danmark Anette Bjørn, Region Syd-Danmark

Susanne G. Sørensen, Region Nord-Jylland, Danmark Anya S. Midjord og Gudna á Rógvi Joensen, LSH-sykehuset, Færøyene Isa-Maria Bergman, Motiva, Finland Outi Kalske, sykehusdistrikt Sør-vest, Finland Karólína Guðmundsdóttir, Landspítali Háskólasjúkrahús, Island
Trude Ertresvåg, Sykehuspartner HF, Norge Kine Stjern og Evy Pleym, Sykehusinnkjøp HF, Norge Anna Chistiansson, Upphandlingsmyndigheten, Sverige Anja Ekstrand og Sofie Areborn, Region Skåne, Sverige Jonna Bjuhr Männer, Koncernkontoret Region Västra Götaland, Sverige Christina Nukala-Pengel, Ålands Hälso- och Sjukvård, Åland Rikke Dreyer og Lena Stenseng, Ecolabel Danmark Weronika Rehnby, TEKO Malin Hill, Berendsen $A B$ Hanne Selsholt Britz og Søren Vinzent, De Forenede Dampvaskerier A/S Fredrik Johansen, FOV Fabrics $A B$ Kate Riley, Oakdene Hollins Rikke Fisher-Bogason og David Watson, PlanMiljø Marie Pettersson og Daniel Eriksson, TEM

Birgitte Jørgensen Kjær og Anne-Mette Lysemose Bendsen, Miljøstyrelsen, Danmark

Spørsmål om veiledningen og nettverket kan sendes til Birgitte Jørgensen Kjær, Miljøstyrelsen, Danmark: bjk@mst.dk

\footnotetext{
${ }^{13}$ http://susproc.jrc.ec.europa.eu/textiles/docs/141222\%20EU\%20GPP\%2OTextiles_Technical\%2Obackground\%2Oreport_Draft\%20 version\%201.pdf
} 
Nordiska ministerråd

Ved Stranden 18

DK-1061 København K

www.norden.org

Denne veiledningen er rettet mot innkjøpere i den nordiske helsesektoren som har ansvar for å kjøpe inn tekstilprodukter og -tjenester. Den har som formål å hjelpe dem å utvikle prosesser for etablering av egnede og praktisk anvendelige miljøkriterier for anbudsdokumenter. Innkjøpere kan lære hvilke sider ved produksjon og vedlikehold av tekstiler som har størst miljøbetydning, og hvordan de kan håndteres ved hjelp av kriterier. De kan lære mer om rollen til miljømerker i innkjøp og finne lenker til bruksklare kriterier og annen nyttig informasjon fra nasjonale innkjøpsorganisasjoner. Veiledningen er utviklet i samarbeid med et nordisk nettverk av innkjøpere i helsesektoren som et ledd i et tiltak i den nordiske handlingsplanen for bærekraftige moteartikler og tekstiler med navnet "Well-dressed in a Clean Environment" ("Velkledd i et rent miljø"). Det finansieres av Nordisk ministerråd. 